\title{
Correction to: Benefit Duration and Return to Work Outcomes in Short Term Disability Insurance Programs: Evidence from Rhode Island's Temporary Disability Insurance Program
}

\author{
Annette M. Bourbonniere ${ }^{1}$. David R. Mann ${ }^{2}$
}

Published online: 26 June 2018

๑) Springer Science+Business Media, LLC, part of Springer Nature 2018

\section{Correction to: Journal of Occupational Rehabilitation https://doi.org/10.1007/s10926-018-9779-5}

The original version of this article unfortunately contained a mistake in the article title. The text "Rhode Island's" inadvertently omitted in the original publication.

The correct article title is "Benefit Duration and Return to Work Outcomes in Short Term Disability Insurance Programs: Evidence from Rhode Island's Temporary Disability Insurance Program"

The original article can be found online at https://doi.org/10.1007/ s10926-018-9779-5.

David R. Mann

dmann@mathematica-mpr.com

Annette M. Bourbonniere

abourbonniere@uri.edu

1 University of Rhode Island, 1 Greenhouse Road, Kingston, RI 02881, USA

2 Mathematica Policy Research, P.O. Box 2393, Princeton, NJ 08543-2393, USA 